\title{
PERANAN SALURAN DISTRIBUSI TERHADAP PENJUALAN TEH SIDAMANIK GAJAH CV. BINTANG TIMUR LAUT PEMATANGSIANTAR
}

\author{
Oleh: \\ Jumady \\ S1 Manajemen \\ Darwin Lie, Marisi Butarbutar, Efendi
}

\begin{abstract}
Abstraksi
CV. Bintang Timur Laut Pematangsiantar adalah perusahaan yang bergerak dalam bidang pengepakan dan penjualan teh. Dalam melakukan penjualan Teh Sidamanik Gajah, CV. Bintang Timur Laut Pematangsiantar menggunakan saluran distribusi dua tingkat selain untuk menghemat biaya, penyaluran produk Teh Sidamanik Gajah dapat mencakup wilayah yang lebih luas serta konsumen tidak mengalami kesulitan dalam memperoleh Teh Sidamanik Gajah. Adapun masalah yang diteliti adalah bagaimana peranan saluran distribusi terhadap penjualan Teh Sidamanik Gajah pada CV. Bintang Timur Laut Pematangsiantar?

Kesimpulan dari penelitian ini adalah penjualan Teh Sidamanik Gajah mengalami peningkatan. Hasil tersebut dinyatakan dalam hasil perhitungan analisis trend yaitu $Y^{\prime}=27,45+1,16 X$ yang artinya bahwa saluran distribusi berbanding positip dalam meningkatkan penjualan Teh Sidamanik Gajah pada CV. Bintang Timur Laut Pematangsiantar. Adapun saran dalam penelitian ini adalah perusahaan perlu meningkatkan jumlah perantara dalam saluran distribusi, memberikan dorongan berupa promosi baik berupa potongan penjualan maupun undian berhadiah
\end{abstract}

Kata kunci : Saluran Distribusi dan Penjualan

Abstract

$C V$. Bintang Timur Laut Pematangsiantar is a company engaged in the field of packing and sale of tea . In selling Sidamanik Gajah Tea, CV. Bintang Timur Laut Pematangsiantar using distribution channels other two levels to save on costs, distribution Sidamanik Gajah Tea products can include a wider region as well as consumers have no difficulty in obtaining Sidamanik Gajah Tea. As for the problem studied is how the role of distribution channel for the sale of Sidamanik Gajah Tea on CV. Bintang Timur Laut Pematangsiantar?

The conclusion from this study is the sale of Sidamanik Gajah Tea increased. Revenue is recognized in the calculation of trend analysis $Y^{\prime}=27,45+1,16 X$ that is that means that the distribution channel than in increasing sales of Sidamanik Gajah Tea is positif at CV. Bintang Timur Laut Pematangsiantar. As for advice in this research is to increase the number of intermediary companies in the distribution channel, providing encouragement whether it be a form of promotion or sale of lottery prizes cuts

Keywords: Distribution Channel and Sales

\section{A. PENDAHULUAN}

\section{Latar Belakang Masalah}

CV Bintang Timur Laut Pematangsiantar yang merupakan perusahaan yang bergerak dalam bidang pengepakan dan penjualan Teh Sidamanik Gajah. Dalam melakukan penjualannya perusahaan banyak mengalami perubahan tingkat penjualan baik kenaikan maupun penurunan penjualan yang disebabkan oleh berbagai faktor. Hal tersebut terlihat pada penurunan penjualan yang terjadi pada semester kedua. Penurunan tersebut disebabkan oleh adanya kesulitan dalam memasarkan produk Teh Sidamanik Gajah karena banyak terdapat pesaing dalam pasar. Sementara pada semester ketiga sampai dengan semester kelima terjadi peningkatan penjualan produk Teh Sidamanik Gajah yang disebabkan oleh adanya kemampuan para pedagang untuk memasarkan produk tersebut. Namun pada semester berikutnya terjadi penurunan kembali yang disebabkan karena banyaknya pengecer yang tidak aktif dan penurunan penjualan oleh pedagang yang masih aktif.

Penjualan yang dilakukan selama ini oleh CV. Bintang Timur Laut Pematangsiantar semuanya tergantung pada saluran distribusi yang dipakai. Perusahaan menggunakan saluran distribusi dua tingkat. Saluran distribusi yang digunakan sesuai dengan kebutuhan perusahaan karena dengan mengunakan saluran distribusi dua tingkat, maka Teh Sidamanik Gajah akan lebih mudah untuk dipasarkan kepada konsumen mengingat cakupan wilayah yang cukup luas serta dapat menghemat biaya daripada tidak menggunakan saluran distribusi. Penting bagi perusahaan untuk mengetahui peranan saluran distribusi terhadap penjualan Teh Sidamanik Gajah agar kedepannya perusahaan dapat mengambil 
strategi jangka pendek maupun jangka panjang secara tepat.

\section{Rumusan Masalah}

Berdasarkan latar belakang masalah di atas, yang menjadi rumusan masalah adalah :

a. Bagaimana kegiatan saluran distribusi yang dilakukan dalam proses penjualan pada CV. Bingtang Timur Laut Pematangsiantar?

b. Bagaimana peranan saluran distribusi terhadap penjualan Teh Sidamanik Gajah pada CV. Bintang Timur Laut Pematangsiantar?

\section{Tujuan Penelitian}

Adapun tujuan penelitian ini adalah :

a. Untuk mengetahui proses kegiatan saluran distribusi yang dilakukan dalam proses penjualan.

b. Untuk mengetahui peranan saluran distribusi terhadap penjualan Teh Sidamanik Gajah pada CV. Bintang Timur Laut Pematangsiantar.

\section{Metode Penelitian}

Dalam penelitian ini, menggunakan metode kepustakaan dan lapangan. Jenis data kualitatif dan kuantitatif, dengan metode pengumpulan data dengan observasi, wawancara dan dokumentasi yang bersumber dari data primer dan skunder dan dianalisa dengan analisa deskriptif dan komparatif.

\section{B. LANDASAN TEORI}

\section{Saluran Distribus}

Menurut Machfoedz (2007:102), saluran distribusi adalah kelompok individu atau perusahaan yang mengarahkan aliran produk dari produsen ke konsumen. Menurut Kotler dan Keller (2009:112), tingkatan saluran distribusi :

a. Aliran fisik

Pemasok - pengangkut gudang - produsen pengangkut gudang - penyalur - pengangkut pelanggan.

b. Aliran hak milik

Pemasok - produsen - penyalur - pelanggan.

c. Aliran pembayaran

Pemasok - bank - produsen - bank - penyalur - bank - pelanggan.

d. Aliran informasi

Pemasok - pengangkut, gudang bank produsen - pengangkut, gudang bank penyalur - pengangkut, bank - pelanggan.

e. Aliran promosi

Pemasok - agensi iklan - produsen - agensi iklan - penyalur - pelanggan.

Menurut Machfoedz (2007:108), faktorfaktor yang mempengaruhi saluran distribusi yaitu

1) Pertimbangan pasar

2) Pertimbangan produk

3) Pertimbangan perusahaan

4) Pertimbangan perantara

Menurut Kotler dan Armstrong (2009:54), perantara adalah orang yang menghubungkan produsen dan konsumen, atau yang menghubungkan antara pedagang besar dengan konsumen. Menurut Kotler dan Armstrong (2009:77), jenis-jenis perantara terdiri atas: Pengeceran dan Pedagang grosir

\section{Penjualan}

Menurut Kartajaya (2010:2), penjualan adalah sebuah proses yang memiliki tahapan yang menuntut keterampilan yang berbeda. Menurut Swasta dalam Yasin (2009:6), penjualan adalah ilmu dan seni mempengaruhi pribadi yang dilakukan oleh penjual untuk mengajak orang lain agar bersedia membeli barang atau jasa yang ditawarkan.

Menurut Swasta dalam Yasin (2009:6), faktor-faktor yang mempengaruhi penjualan yaitu:

a. Kondisi dan kemampuan penjual

b. Kondisi pasar

c. Modal

d. Kondisi organisasi perusahaan

e. Faktor lain

Menurut Boyd, et. al. (2000:105), proses penjualan terdiri atas 6 tahap yaitu:

1) Menentukan calon pelanggan

2) Membuka hubungan

3) Mengkualifikasi calon pelanggan

4) Mempresentasikan pesan penjualan

5) Memastikan penjualan

6) Melayani pelanggan

\section{PEMBAHASAN}

\section{Analisa}

CV. Bintang Timur Laut Pematangsiantar dalam menyalurkan produknya menggunakan saluran distribusi dua tingkat yaitu dimulai dari produsen kemudian pedagang grosir, pengecer dan terakhir kepada konsumen akhir. Saluran distribusi yang digunakan oleh CV. Bintang Timur Laut Pematangsiantar berada di dua daerah yaitu daerah kota Pematangsiantar dan sekitarnya kemudian berada di kota Medan dan sekitarnya.

Untuk dapat menyalurkan produknya, perusahaan menggunakan sales berserta alat angkut berupa mobil box untuk membawa produknya dari tempat produksi menuju saluran distribusi. Kegiatan mengangkut produk tersebut mengakibatkan adanya biaya-biaya yang harus dibayar. Biaya-biaya yang harus dikeluarkan adalah berupa minyak kendaraan, uang makan, gaji sales, penyusutan kendaraan, serta biaya-biaya tidak terduga lainnya seperti biaya bongkar muat.

Berdasarkan hasil pengumpulan data, maka dapat dirangkum jumlah biaya yang telah digunakan selama sembilan semester yang dimulai dari Desember 2007 sampai dengan Mei 2012. Berikut ini ditampilkan tabel rekapitulasi biaya yang digunakan dalam menyalurkan teh Sidamanik Gajah:

\section{Tabel 1}

Rekapitulasi Jumlah Biaya Saluran Distribusi

\begin{tabular}{|c|c|c|}
\hline Semester & $\begin{array}{c}\text { Biaya Saluran Distribusi } \\
\text { (Juta Rupiah) }\end{array}$ & Persentase \\
\hline
\end{tabular}




\begin{tabular}{|c|c|c|}
\hline I & 11,844 & $100 \%$ \\
\hline II & 12,277 & $103,66 \%$ \\
\hline III & 15,155 & $127,91 \%$ \\
\hline IV & 16,275 & $137,41 \%$ \\
\hline V & 16,928 & $142,91 \%$ \\
\hline VI & 16,605 & $140,20 \%$ \\
\hline VII & 16,736 & $141,30 \%$ \\
\hline VIII & 27,057 & $228,44 \%$ \\
\hline IX & 26,607 & $223,65 \%$ \\
\hline
\end{tabular}

Sumber: CV Bintang Timur Laut Pematangsiantar

Berdasarkan tabel di atas, dapat dilihat bahwa pada awal semester biaya yang digunakan adalah sejumlah 11,844 juta rupiah. Kemudian pada semester kedua terjadi kenaikan biaya sejumlah 12,277 juta rupiah. Jika dihitung secara persentase maka terjadi kenaikan sebesar 3,66\% dari semester satu. Hal ini dikarenakan perusahaan berusaha mencari perantara yang baru namun masih dalam jarak yang tidak terlalu jauh dari saluran distribusi yang telah ada.

Pada semester ketiga masih terjadi kenaikan biaya dalam kegiatan saluran distribusi. Kenaikan tersebut sedikit lebih tinggi yaitu sebesar 2,878 juta rupiah dibandingkan pada semester kedua. Jika dibandingkan dengan semester pertama maka terjadi peningkatan sebesar $27,41 \%$. Hal ini disebabkan karena adanya biaya-biaya tidak terduga ketika melakukan kegiatan penyaluran seperti penggantian suku cadang kendaraan ketika menyalurkan produk.

Pada semester keempat, biaya masih sedikit meningkat dibandingkan dengan semester kedua dan semester ketiga yaitu sebesar 1,120 juta rupiah dibandingkan semester ketiga. Namun persentase jika dibandingkan dengan semester awal maka terjadi kenaikan sejumlah 37,41\%. Hal tersebut terjadi dikarenakan adanya biaya operasional yang meningkat dari segi minyak kendaraan.

Pada semester kelima peningkatan biaya masih terjadi, namun peningkatan tersebut sangat sedikit jika dibandingkan semester sebelumnya. Peningkatan tersebut hanya 653 ribu rupiah dari semester kelima. Namun jika dibandingkan dengan semester awal maka terjadi peningkatan sebesar $42,92 \%$. Kenaikan yang tidak begitu mencolok masih dianggap wajar oleh perusahaan.

Pada semester keenam, biaya yang digunakan terjadi penurunan jika dibandingkan pada semester kelima walaupun penurunan hanya sebesar 323 ribu rupiah. Namun jika dibandingkan dengan semester awal maka terjadi peningkatan sejumlah 40,2\%. Hal ini dikarenakan CV. Bintang Timur Laut Pematangsiantar berusaha untuk mengurangi beban biaya yang digunakan melalui pemilihan jalur jalan yang lebih efisien.

Pada semester ketujuh, terjadi kenaikan biaya kembali. Namun kenaikan biaya ini hanya sebesar 131 ribu rupiah. Kenaikan ini dianggap wajar mengingat situasi dan kondisi yang ada pada saat itu. Namun jika dibandingkan dengan semester awal makan terjadi kenaikan sebesar 41,30\%

Pada semester kedelapan, terjadi pelonjakan biaya yang sangat tinggi yaitu sebesar 10,321 juta rupiah jika dibandingkan dengan semester ketujuh. Hal ini disebabkan karena berbagai faktor seperti permintaan kenaikan gaji sales, penambahan karyawan, dan biaya tidak terduga lainnya.jika dibandingkan dengan semester awal maka peningkatan biaya adalah sebesar $128,44 \%$.

Pada semester kesembilan biaya yang digunakan kembali mengalami penurunan walaupun hanya sebesar 450 ribu rupiah jika dibandingkan semester kedelapan. Dalam hal ini perusahaan terus mencoba menekan biaya seminimal mungkin. Namun jika dibandingkan dengan semester awal, maka peningkatan biaya masih sangat tinggi yaitu sebesar 123,65\%.

Selain data jumlah biaya, juga sudah dikumpulkan data-data dari penjualan dari semester satu sampai dengan semester sembilan. Berikut ditampilkan data tabel rekapitulasi jumlah penjualan selama sembilan semester dalam rupiah.

Tabel 2

Rekapitulasi Jumlah Penjualan

\begin{tabular}{|c|c|c|}
\hline Semester & $\begin{array}{c}\text { Total Penjualan } \\
\text { (Juta Rupiah) }\end{array}$ & Persentase \\
\hline I & 37,885 & $100 \%$ \\
\hline II & 37,561 & $99,15 \%$ \\
\hline III & 45,464 & $120,01 \%$ \\
\hline IV & 46,172 & $121,87 \%$ \\
\hline V & 49,768 & $131,37 \%$ \\
\hline VI & 48,631 & $128,37 \%$ \\
\hline VII & 51,489 & $135,91 \%$ \\
\hline VIII & 52,452 & $138,45 \%$ \\
\hline IX & 62,652 & $165,37 \%$ \\
\hline
\end{tabular}

Sumber : CV. Bintang Timur Laut Pematangsiantar

Berdasarkan tabel tingkat penjualan diatas, dapat dilihat bahwa penjualan teh Sidamanik Gajah CV. Bintang Timur Laut Pematangsiantar pada semester I adalah sebesar 37,885 juta rupiah. Hasil tersebut dikarenakan CV. Bintang Timur Laut Pematangsiantar masih berusaha mencari pengecer baru sebagai bagian dari saluran distribusinya.

Pada semester II, penjualan Teh Sidamanik Gajah mengalami sedikit penurunan sebesar 324 ribu rupiah. Pada semester ini terjadi peningkatan penjualan pada pedagang grosir. Namun terjadi penurunan penjualan pada pengecer. Penurunan tersebut terjadi dikarenakan para pengecer kesulitan dalam memasarkan produk teh tersebut. Kesulitan tersebut terjadi karena kurangnya daya tarik dari Teh Sidamanik Gajah yang ditawarkan oleh perusahaan. Dalam persentase terjadi penurunan sebesar $0,85 \%$.

Pada semester III, penjualan Teh Sidamanik Gajah mengalami kenaikan sebesar 7,903 juta rupiah dari semester sebelumnya. Namun jika dibandingkan dengan semester awal, maka terjadi peningkatan sebesar 20,01\%. Hal ini terjadi dikarenakan para perantara rata-rata telah mampu untuk menawarkan produk kepada konsumen. Namun tidak semua pengecer yang mengalami peningkatan penjualan. 
Pada semester IV penjualan Teh Sidamanik Gajah mengalami peningkatan sebesar 708 ribu rupiah dari semester sebelumnya. Namun jika dibandingkan dengan semester awal maka terjadi peningkatan sebesar 28,17\%. Hal tersebut dikarenakan penjualan pihak pengecer mengalami penurunan dari semester sebelumnya. Adanya pengecer yang tidak sanggup mempertahankan tingkat penjualan produknya. Namun saluran grosir masih mampu untuk terus meningkatkan penjualannya. Sehingga dari hasil data yang dirangkum, penjualan masih mengalami kenaikan walaupun tidak banyak.

Pada semester $\mathrm{V}$ penjualan Teh Sidamanik Gajah masih mengalami peningkatan sejumlah 3,596 juta rupiah dari semester sebelumnya. Namun jika dibandingkan dengan semester awal maka terdapat peningkatan sebesar $31,37 \%$. Hal ini dikarenakan adanya penjualan yang dilakukan oleh pengecer maupun grosir hampir tidak memiliki perubahan dari semester sebelumnya. Namun secara rinci terdapat peningkatan penjualan oleh sebagian pengecer, namun ada juga pengecer yang sudah tidak menjual produk teh tersebut.

Pada semester VI penjualan Teh Sidamanik Gajah mengalami penurunan dari semester sebelumnya sejumlah 1,137 juta rupiah. Namun jika dibandingkan dengan semester awal maka terjadi peningkatan sebesar $28,37 \%$. Hal tersebut terjadi karena pengecer mengalami penurunan penjualan disertai dengan adanya pengecer yang sudah tidak aktif lagi. Namun dilihat dari penjualan grosir masih mengalami peningkatan dari semester sebelumnya.

Pada semester VII penjualan Teh Sidamanik Gajah mengalami peningkatan yang cukup tinggi yaitu sebesar 2,858 juta rupiah. Jika dibandingkan dengan semester awal maka terdapat peningkatan sebesar $35,91 \%$. Hal tersebut dikarenakan adanya penambahan pengecer yang baru dibarengi dengan peningkatan jumlah penjualan pada pedagang grosir.

Pada semester VIII penjualan Teh Sidamanik Gajah mengalami peningkatan sebesar 963 ribu rupiah. Jika dibandingkan dengan semester awal penjualan mengalami peningkatan sebesar $38,45 \%$. Hal ini terjadi karena adanya kenaikan harga satuan penjualan yang semula Rp. 8.500,00 untuk pengecer dan Rp. 8.000,00 untuk pedagang grosir menjadi Rp. $10.000,00$ untuk pengecer dan Rp. 9.500,00 untuk pedagang grosir. Namun jika dilihat dari segi jumlah satuan per bal-nya mengalami penurunan dalam penjualan.

Pada semester IX penjualan Teh Sidamanik Gajah masih mengalami kenaikan sebesar 10,2 juta rupiah. Jika dilihat dari perbandingan awal semester maka terjadi peningkatan sebesar $65,37 \%$. Hal ini dikarenakan konsumen sudah terbiasa dengan kenaikan harga yang terjadi pada semester sebelumnya. Sehingga pihak perantara dapat meningkatkan penjualannya kembali.
Bardasarkan data kedua tabel diatas, dapat dicari peranan saluran distribusi terhadap penjualan melalui metode analisis trend dan diperoleh hasil $Y^{\prime}=27,45+1,16 X$ yang artinya bahwa saluran distribusi berbanding positip dalam meningkatkan penjualan Teh Sidamanik Gajah CV. Bintang Timur Laut Pematangsiantar

\section{Evaluasi \\ a. Saluran Distribusi \\ Berdasarkan tingkatan saluran yang} digunakan oleh CV. Bintang Timur Laut Pematangsiantar, bahwa saluran distribusi yang digunakan sudah tepat. Namun kurang banyaknya perantara pedagang grosir dan pengecer mengakibatkan penjualan Teh Sidamanik Gajah meningkat secara perlahan. Banyaknya pengecer yang tidak aktif, mengharuskan CV. Bintang Timur Laut Pematangsiantar harus mencari pengecer lainnya serta membuat pengecer yang tidak aktif menjadi aktif kembali dengan cara memberikan dorongan berupa promosi baik berupa potongan harga maupun undian berhadiah jika hal tersebut memungkinkan. Untuk pedagang grosir sendiri perlu diperbanyak lagi jumlahnya sehingga memungkinkan peningkatkan penjualan Teh Sidamanik Gajah secara berkelanjutan

b. Penjualan

Berdasarkan pembahasan sebelumnya, dapat dilihat bahwa penjualan Teh Sidamanik Gajah telah mengalami peningkatan. Akan tetapi peningkatan penjualan yang terjadi tidak begitu tinggi. Pada semester VIII terjadi peningkatan yang cukup meningkat dalam segi harga. Namun jika dilihat dari segi per satuan bal, maka yang terjadi adalah penurunan penjualan Teh Sidamanik Gajah. hal tersebut terjadi karena faktor kenaikan harga disertai adanya persaingan dengan perusahaan lain yang menjual produk homogen dengan harga yang lebih terjangkau. Faktor lainnya adalah kurangnya minat konsumen terhadap produk teh Sidamanik Gajah. Untuk itu, CV. Bintang Timur Laut Pematangsiantar harus memperhatikan konsekuensi ketika akan menaikkan harga Teh Sidamanik Gajah. Selain itu, CV. Bintang Timur Laut Pematangsiantar dapat menambahkan upaya promosi ketika hendak menaikkan harga Teh Sidamanik Gajah.

\section{KESIMPULAN DAN SARAN 1. Kesimpulan}

Adapun kesimpulan yang dapat diambil adalah sebagai berikut:

a. Saluran distribusi yang dilakukan oleh CV. Bintang Timur Laut Pematangsiantar adalah saluran distribusi produk dengan menggunakan saluran dua tingkat yaitu dengan menggunakan perantara pedagang grosir dan pengecer.

b. Berdasarkan data-data biaya saluran distribusi Teh Sidamanik Gajah yang dilakukan oleh CV. Bintang Timur Laut Pematangsiantar pada semester VIII mengalami peningkatan yang 
cukup tinggi adanya kenaikan biaya operasional dalam menyalurkan produk seperti kenaikan gaji sales, penambahan karyawan, dan biaya tidak terduga lainnya yaitu seperti penggantian suku cadang kendaraan yang digunakan untuk menyalurkan produk.

c. Berdasarkan hasil analisa yang telah dilakukan, terlihat bahwa penjualan Teh Sidamanik Gajah mengalami peningkatan. Hasil tersebut dinyatakan dalam hasil perhitungan analisis trend yaitu $Y^{\prime}=27,45+1,16 X$ yang artinya bahwa saluran distribusi berbanding positip dalam meningkatkan penjualan Teh Sidamanik Gajah pada CV. Bintang Timur Laut Pematangsiantar, dimana dalam setiap pertambahan 1 (satu) satuan biaya saluran distribusi akan mengakibatkan pertambahan penjualan sebanyak 1,16 kali.

\section{Saran}

Adapun saran yang dapat diberikan adalah sebagai berikut:

a. Dalam usaha meningkatkan penjualan Teh Sidamanik Gajah dimasa yang akan datang, perusahaan perlu meningkatkan jumlah perantara dalam saluran distribusi yang selama ini telah berperan dalam penjualan.

b. Banyaknya perantara yang kurang aktif, hendaknya lebih diperhatikan dengan memberikan dorongan berupa promosi baik berupa potongan penjualan maupun undian berhadiah jika memungkinkan sehingga perantara yang kurang aktif menjadi lebih bersemangat dan menjadi aktif dalam menjual produk Teh Sidamanik Gajah.

c. Harga produk yang akan dinaikkan sebaiknya ditinjau ulang kembali agar penjualan yang terjadi tidak mengalami penurunan yang signifikan. Namun jika harga yang akan dinaikkan tidak dapat di hindarkan, maka CV. Bintang Timur Laut Pematangsiantar sebaiknya memberikan berbagai promosi agar konsumen tidak berpindah ke produk teh pesaing.

\section{E. DAFTAR PUSTAKA}

Boyd, et. al., 2000, Manajemen Pemasaran: Suatu Pendekatan Strategis dengan Orientasi Global, Jakarta : Erlangga.

Kartajaya, Hermawan, 2010, The Official MIM Academy Coursebook Sales Operation, Jakarta : Esensi.

Kotler, Philip \& Armstrong, Gary, 2009, Prinsipprinsip Pemasaran, Jilid 1\&2, Jakarta : Erlangga.

Kotler, Philip \& Keller, Kevin Lane, 2009, Manajemen Pemasaran, Edisi Ketigabelas, Jilid 1, Jakarta : Erlangga.

Machfoedz, Mahmud, 2007, Pengantar Bisnis Modren, Yogyakarta : Penerbit Andi.

Yasin, Sanjaya, 2009, www.Sarjanaku.com, 2012. 